\title{
BOOSTING INNOVATIVE ENTREPRENEURIAL ECOSYSTEM IN REGIONS FOR YOUNG ENTREPRENEURS - REGIONAL PERSPECTIVE OF ENTREPRENEURSHIP
}

\section{MONIKA TOMCZYK, ${ }^{1}$ MONIKA SPYCHALSKA-WOJTKIEWICZ ${ }^{2}$}

\author{
University of Szczecin, Faculty of Management and Economics of Services, POLAND \\ ${ }^{1}$ e-mail: monika.tomczyk@wzieu.pl \\ 2 e-mail: monika.wojtkiewicz@wzieu.pl
}

RECEIVED

ACCEPTED

JEL

CLASSIFICATION

KEYWORDS

ABSTRACT
18 January 2018

2 September 2018

E02, F63, L21, L26

entrepreneurship, innovative ecosystem, regional development, European founds, Europe

From 2016 till 2020 iEER project partners will learn from each other to build better services and regional policies in order to support startups. The project aims to break down silo mentality and bring together all actors having a hand in entrepreneurial success. Universities, local and regional authorities, entrepreneurship support organisations and SMEs are closely involved in the project both on the local and interregional levels. International studies on macro and micro level are conducted as well as analyses of the regional context of ecosystems supporting the entrepreneurship. Individual perspective of startups and small companies is taking to the account. The article describes practical aspects related to the support of the entrepreneurial ecosystem, which is an additional asset. The research method itself is a method of classical data analysis (desk research) and case studies, but the description of idea how to boost youth entrepreneurship and entrepreneurship ecosystem itself is a new approach. Results of the iEER project analyses are presented in article, as well as comparative study of Westpomerania Region to other regions in Europe. 


\section{Introduction}

Boosting innovative Entrepreneurial Ecosystem in Regions for young entrepreneurs - iEER is an Interreg Europe funded flagship project bringing together 10 regions around Europe ${ }^{1}$. Initiated by a group of regions awarded with the European Entrepreneurial Region label (Committee of the Regions, 2016). The main goal of iEER is to define smart paths and solutions to boost regional entrepreneurship ecosystems supporting young entrepreneurs. iEER partner regions have a strong focus on entrepreneurship and the majority of project partners have been awarded with the European Entrepreneurial Region label (www.interregeurope.eu/ieer, 2017).

\section{Method}

iEER learning process is conducted during 2016-2018. The five Learning Camps are a key element of the project. During Learning Camps project partners study the best practices of a region and brainstorm in workshops to find solutions to common problems. Another central element of the project are ten Peer Reviews, one for each partner region. Peer reviews are design to provide valuable insight on the strengths and weaknesses of the region which will help develop local entrepreneurial ecosystems. After the learning process is concluded in 2018 project findings will be collected, analyzed and compiled into regional action plans, which will then be put into action. Key findings of the learning process will be shared with others through the iEER Boost Growth Handbook. The handbook gathers best practices and most useful policies into a practical guide to benefit other European regions. The second phase of the project sees iEER move from learning to implementation with the help of Structural Funds and other available local and EU funding (www.interregeurope.eu/discover-projects, 12.10.2017). During 2018-2020 regional action plans are put into practice and their progress is closely monitored. The results and lessons learned from the implementation of the action plans are collected into an EU-wide policy recommendation. Regional action plans, iEER Boost Growth Handbook and the policy recommendation are shared to provide others the chance to implement lessons learned. iEER works closely with the EU Committee of the Regions and European Commission DG Growth to make sure project results can be enjoyed by regions around Europe (iEER, 2017).

\section{Results}

\section{Regional policies and strategies}

Taking into account the current situation of the region and its economic development vision, in the upcoming years West Pomerania is likely to face a number of major challenges. The activities of regional authorities will focus on the development of smart specializations (Regional Development Strategy of Smart Specializations in the West Pomerania Region 2020+ RIS3, 2016). This is aimed at expanding the international cooperation and the internationalization of business activities, thus strengthening the competitive power of the region. Increasing the significance of West Pomerania in international markets is a particularly important aspect. It is expected that the smart specializations identified as high-potential areas will act as a magnet for newly established enterprises.

\footnotetext{
${ }^{1}$ Helsinki-Uusimaa Regional Council (Lead Partner), Westpomerania Region, Region of Southern Denmark, University of Applied Sciences Brandenburg, North France Innovation Development, Institute of Technology Tralee Ireland, Northern Ireland Local Government Association, Regional Development Agency of the West Region Romania, Regional Government of Valencia, Marche Regional Authority
} 
The most important issues in the upcoming years will include strengthening and deepening inter-regional cooperation between the market entities concerned, which are aware of the need to exchange experiences and engage in new technological achievements. An equally important role in the economic specialization process is expected to be played by joint actions taken by universities and enterprises in the field of both teaching, and research and development.

In 2016 the West Pomerania authorities adopted the Regional Development Strategy of Smart Specializations in the West Pomerania Region. Nonetheless, based on the binding strategy, no initiatives addressed to enterprises are currently implemented in the region. The Marshal's Office of the Region is preparing a project of establishing and developing the regional innovation system to be launched by the end of 2016 .

Two major modes of financing business development can be identified in region, i.e. instruments based on public resources, coming from both regional and European funds, and private resources coming from private investors or entrepreneurs' own resources. In the case of Polish and West Pomerania enterprises, it can be noted that, despite the relatively wide availability of EU funds, enterprises' own resources are still the prevailing source of financing innovations.

Business awareness among young people is gradually increasing, inter alia, due to searching for various forms of self-employment and finding a way around the problem of unemployment. The need to support entrepreneurship also appears to be increasingly recognized by administrative authorities in the region. This is also reflected in the development of numerous initiatives in the field of entrepreneurship and commercialization, both at higher education establishments and among non-governmental organizations. This proves how the entrepreneurship support eco-system is expanding in the West Pomerania Region. However, the synergy effect arising from the activities of various types of organizations is yet to become more pronounced. For many years political support has been offered by regional authorities for different initiatives promoting entrepreneurship development, also through numerous strategic documents (including the Regional Development Strategy of Smart Specializations in the West Pomerania Region 2020+). Especially important aspects for Region include supporting the R\&D activities and transferring highly innovative and locally developed technologies. The region promotes best practices in the scope of technology through publications and events, including:

- the Information Bulletin of the Regional Operational Programme of the West Pomerania Region 2014-2020,

- the Economic Competition of the Marshal of the West Pomerania Region.

Support is also provided to various initiatives aimed at strengthening the regional economy, innovation and cooperation between the business and research sectors, through:

- business-business and business-science meetings,

- science-promoting events (e.g. the $E(x)$ plory competition),

- training sessions and conferences.

Innovation support is envisaged in several strategic documents concerning the West Pomerania Region, including the Regional Operational Programme of the West Pomerania Region, the Regional Development Strategy of Smart Specializations in Region 2020+, and the Regional Development Strategy. These documents define a number of business support-oriented measures, such as loans, guarantees and support to investments, along with research, land preparation for investments, training sessions, fairs, promotion, consultancy, mentoring, coaching, etc.

This support is assumed to be mainly directed to enterprises, including SMEs introducing novel ideas to the market, and in particular in cooperation with R\&D units and entities operating in the field of smart specializations. 
Other entities which may apply for support for innovation development and implementation, as part of the innovationoriented regional policy, include higher education establishments, organizations supporting entrepreneurship, credit and warranty funds, and incubators.

\section{Structural funds}

The currently implemented Regional Operational Programme of the West Pomerania Region promotes the establishing and development of new enterprises. One of the direct ways of supporting entrepreneurship, self-employment and creation of new jobs is to finance various consulting and training initiatives addressed to people willing to pursue such challenges. Information and publicity campaigns are conducted to promote the idea that it is never too late to commence business activity - you only need a good idea and determination.

The sum of over EUR 340,000,000 has been allocated for the economic sector development as part of the Regional Operational Programme 2014-2020. These resources will be rendered available as part of the First Priority Axis: Innovations - Modern Technologies, aimed at increasing the level of innovation and competition of the regional economy. The Regional Operational Programme is closely correlated with the RIS3 strategy. Therefore, the principal objective of the First Axis is to use the potential of smart specializations, including through increased activeness of enterprises in the field of research and development. The Programme offers support to enterprises at each development stage and is addressed to both companies (directly) and business support institutions (indirectly).

In addition, by hand of the bank-managed West Pomerania Fund of the Joint European Resources for Microto-Medium Enterprises (JEREMIE 2), financial instruments are introduced which support entrepreneurs at the initial stage. These instruments are implemented, inter alia, through the following actions: 1.17 Strengthening the process of supporting companies at the early development stage and 1.9 Investing in enterprises through financial instruments.

Financial resources will be allocated for supporting small and medium-sized enterprises, including start-ups, by providing them with financial instruments in the form of capital contributions, warranties, micro-loans, working capital loans, investment loans, loans for the implementation of R\&D results, and loans for supporting self-employment and creating new jobs.

As part of Action 1.17, comprehensive incubation support has been envisaged, along with capital instruments, including the provision of new and specialized incubation services through consulting measures focused on advanced business planning, product/service marketing, sales process improvement, innovations, risk analysis and acceleration.

With a view to selecting the most promising projects to receive financial support, the Marshal's Office has launched a dedicated department in charge of assessing applications submitted as part of the Regional Operational Programme. At the subsequent stage, experts are engaged to assess the proposed projects before the final decision is made on their financing.

For many years West Pomerania has been invariably in the lead when it comes to regional entrepreneurship. The enterprise-oriented measures taken by the regional authorities are primarily aimed at developing the innovationdriven attitudes among entrepreneurs and increasing the degree of business-science cooperation.

As regards West Pomerania, the development of innovative economy appears of utmost importance, considering that the region is left behind in the innovation ratings. In the previous financial perspective, business support institutions, along with local-government bodies, have displayed a significant level of activeness in 
developing soft support measures and infrastructure for young enterprises. The already implemented measures will soon be supplemented with other means of supporting entrepreneurship. A significant factor to determine the support provided to specific initiatives will be their correlation with the actual market demand.

Therefore, the support instruments as part of the new financial perspective for 2014-2020, within the Regional Operational Programme of the West Pomerania Region, have been mainly oriented towards increasing the level of innovation and competition of the region through smart specializations.

In addition, a sum of over PLN 50,000,000 has been allocated for start-ups financing as part of the JEREMIE initiative (with West Pomerania as the pioneering region). This support measure has provided entrepreneurs with access to a wide array of financial instruments on more favorable conditions. The significant level of flexibility, resulting from an extended withdrawal or settlement period, constitutes an unquestionable asset of this model of financing. The support provided is expected to open new financial opportunities to these enterprises, including especially micro- and small entities, which usually use their own resources to implement innovative solutions.

\section{Entrepreneurial competence and mind-set activation}

Essential aspects of supporting entrepreneurship in the West Pomerania Region include supporting entrepreneurial competences and fostering optimal approach to business orientation. As part of good practices in this field, activities undertaken by the Regional Centre for Innovation \& Technology Transfer (RCliTT) are certainly worth noting. The Regional Centre for Innovation \& Technology Transfer operates within the West Pomeranian University of Technology in Szczecin which was established in 2009 by combining the Agricultural University and the Szczecin University of Technology. RCliTT was set up in 2008 within the International Programmes Office operating since 1999.

RCliTT conducts advisory and training activities addressed to enterprises, scientists, students and graduates, in the field of technology transfer, research and development financing, and support to academic entrepreneurship. An array of RCliTT services are offered free of charge, using the funds provided by the European Commission and the Ministry of Science and Higher Education. The top quality of services is confirmed by the quality certificate ISO 9001:2008 (ZUT, 2017).

With a view to supporting entrepreneurial competencies and business orientation, RCliTT also runs the Academic Business Incubator. It also deals with consultancy services concerning research and development, as well as legal scholarships, internships and vacancies, and provides information on the administrative and formal aspects of scientists' mobility.

Technopark Pomerania is another institution supporting entrepreneurial competences, and promoting entrepreneurial attitudes and business orientation. Technopark is a complex of facilities managed by the Szczecin Scientific and Technological Park which implements enterprise development support programmes, and also facilitates office rental and renders data centre services (Technopark Pomerania, 2017).

\section{Staptup and acceleration support}

In terms of supporting entrepreneurship, the support for newly formed enterprises and start-ups, and business acceleration appear equally significant as training or advisory activities. However, at this stage the use of different tools and tailored problem-solving strategies seems indispensable. As part of good practices in this field, activities 
undertaken by the Regional Centre for Innovation \& Technology Transfer are again worth noting, in the context of the Academic Business Incubator run by this institution.

The services provided by the RCliTT ABI are aimed at supporting entrepreneurs at the pre-incubation, incubation and acceleration stages (Inkubator Przedsiębiorczości, 2017). In the process of establishing start-up activities, and then in the course of acceleration and scaling, it is extremely important that appropriate infrastructure support and mentoring be provided. For this reason, ABls also offer support in business modeling, identifying strengths and weaknesses, and analyzing business surrounding and competition. It also conducts training on financing, protection of intellectual property rights, and business internationalization.

\section{Conclusions}

While analyzing the activities of RCliTT and Technopark, one can observe certain differences in the concept of supporting entrepreneurial competences and promoting entrepreneurial attitudes. These differences, however, make the two institutions complementary rather than competitive to each other. In the regional context, these are the most significant and dynamic institutions. Business support institutions and local-government units have displayed a significant level of activity in the field of expanding the incubation infrastructure for newly established enterprises and technological parks. Structural funds and other public resources have contributed to the emergence of new innovation support services in the market (Regional Development Strategy of Smart Specialisations in the Westpomerania Region 2020+ RIS3, 2016). The Regional Development Strategy of Smart Specializations in the West Pomerania Region $2020+$ is a guidance document which also bears certain operational features, indicating the need to support young entrepreneurs, including through strengthening the human capital, improving the structure of business connections, fostering the cooperation between business support institutions, and developing scientific potential.

\section{References}

Inkubator Przedsiębiorczości (2017). Retrieved from: www.innowacje.zut.edu.pl/inkubator-przedsiebiorczosciofertaudostepnian ie-pomieszeczenkonkursy-na-nabor.

iEER Information package (2017). Interreg Europe. Helsinki-Ussima.

Interreg Europe (2017). Retrieved from: www.interregeurope.eu/ieer.

Interreg Europe (2017). Retrieved from: www.interregeurope.eu/discover-projects.

Regional Development Strategy of Smart Specialisations in the Westpomerania Region 2020+ RIS3 (2016). Województwo Zachodniopomorskie, Szczecin.

Technopark Pomerania (2017). Retrieved from: www.technopark-pomerania.pl/pl/o-nas/podstawowe-informacje.

The European Entrepreneurial Region (EER), Encouraging entrepreneurship at local and regional level (2016). Committee of the Regions, Brussel.

ZUT (2017). Retrieved from: www.innowacje.zut.edu.pl/o-nas.

Cite this article aS: Tomczyk, M., Spychalska-Wojtkiewicz, M. (2018). Boosting innovative entrepreneurial ecosystem in regions for young entrepreneurs - regional perspective of entrepreneurship. European Journal of Service Management, 3 (27/2), 499-504. DOI: 10.18276/ejsm.2018.27/2-61. 